Abstracta Iranica

Revue bibliographique pour le domaine irano-aryen

Volume 29 | 2008

Comptes rendus des publications de 2006

\title{
TārīH-e taṣavvof, 1, Tehrān, SAMT, 1384/2005, 306 p. [Histoire du soufisme]
}

\section{Ève Feuillebois-Piérunek}

\section{(2) OpenEdition}

\section{Journals}

\section{Édition électronique}

URL : http://journals.openedition.org/abstractairanica/30422

DOI : 10.4000/abstractairanica.30422

ISSN : 1961-960X

Éditeur :

CNRS (UMR 7528 Mondes iraniens et indiens), Éditions de l'IFRI

\section{Édition imprimée}

Date de publication : 15 mai 2008

ISSN : 0240-8910

\section{Référence électronique}

Ėve Feuillebois-Piérunek, «Tārīh-e tașavvof, 1, Tehrān, SAMT, 1384/2005, 306 p. [Histoire du soufisme] », Abstracta Iranica [En ligne], Volume 29 | 2008, document 292, mis en ligne le 15 septembre 2008, consulté le 26 septembre 2020. URL : http://journals.openedition.org/abstractairanica/30422 ; DOI : https://doi.org/10.4000/abstractairanica.30422

Ce document a été généré automatiquement le 26 septembre 2020.

Tous droits réservés 


\section{TārīH-e taṣavvof, 1, Tehrān, SAMT, 1384/2005, 306 p. [Histoire du soufisme]}

Ève Feuillebois-Piérunek 
1 Les AA. entendent écrire une histoire du soufisme en trois tomes, dont voici le premier. Deux chapitres introductifs présentent les principales notions et définitions, et font état des avis et jugements sur le soufisme de divers courants de pensée musulmans (docteurs de la Loi, philosophes).

2 Le troisième chapitre est un exposé historique allant de la genèse du mouvement jusqu'au XIII ${ }^{\mathrm{e}}$ s. environ. Pour chaque siècle, un exposé général synthétise la période, puis les personnalités les plus importantes sont présentées, essentiellement à partir de sources primaires (țabaqāt). Si la synthèse ne contient pas d'erreur trop flagrante, la présentation des personnages est indigente : des éléments biographiques dont la fiabilité n'est pas établie, une liste d'œuvres sans essai de classement ou de caractérisation, pas d'analyse de la doctrine ou des spécificités de l'auteur. Les AA. se conduisent en pionniers et ne tiennent absolument pas compte des recherches occidentales et même iraniennes sur le soufisme. Zarrīnkūb, qui poursuivait le même objectif que les auteurs dans TārïH-e tașavvof n'est pas cité dans cet ouvrage.

Dans le quatrième chapitre, consacré au cheminement spirituel (seyr va solūk), les auteurs proposent un classement modernisé des étapes à partir de la synthèse d'auteurs d'époques et de milieux différents. Pourquoi vouloir harmoniser artificiellement ce qui ne l'a jamais été dans la réalité ? L'ouvrage se termine par une partie sur les confréries et les courants soufis qui se trouvent assimilés à des schismes tels qu'il en existe dans le christianisme. De plus, de simples orientations (sectateurs de Uveys ou de Ḥasan al-Bașrī) sont mises sur le même pied que les confréries institutionnalisées.

4 A cause de ces importants problèmes méthodologiques, ce livre ne sera pas utile au chercheur occidental, mais constitue néanmoins une tentative intéressante pour rendre le soufisme moins diabolique aux yeux de ses détracteurs orthodoxes.

\section{INDEX}

Thèmes : 8 . Soufisme

\section{AUTEURS}

\section{ÈVE FEUILLEBOIS-PIÉRUNEK}

Sorbonne Nouvelle-Paris III - Mondes iranien et indien 